wooden floor. The purpose was to facilitate a wider range of uses of the building for the purposes of mission and outreach, and in particular for a Café Church initiative in which worshippers sit at round tables. The Victorian Society objected and, in particular, criticised as wholly inadequate the Statement of Significance prepared by the petitioners. This statement had failed adequately to note the significance of the work of the Victorian architect Henry Woodyer in the reordering of the church in 1872 . The chancellor was satisfied that, whilst the statement was inadequate, it had not affected the decision of the DAC to recommend the works proposed, and that it had been replaced with a satisfactory statement prior to the hearing. The chancellor considered the Bishopsgate questions. He followed the decisions in Re St Mary the Virgin Essendon (2001) 6 Ecc LJ 415 and Re Holy Cross, Pershore [2002] Fam 1 in holding that outreach and mission are important considerations. He permitted the replacement of the pews with chairs, holding that the necessity outweighed the effect on the character of the building and permitted the installation of a wooden floor as being a visual and practical improvement on the current tiled floor. He refused to permit the removal of the font, which dates from medieval times and was altered by Woodyer in 1872 , as its retention would have marginal negative impact on the proposed future use of the building. [WA]

doi:10.1017/So956618X10000608

\title{
Re St Bartholomew, Horley
}

Southwark Consistory Court: Petchey Dep Ch, February 2010 Exhumation - special circumstances

The deceased's cremated remains were buried some 90 yards from the grave of his wife who had died very unexpectedly 13 months after the death of the deceased. Their four children sought the exhumation of the deceased's remains for their reinterment in his wife's grave. Given his wife's expressed desire to be buried, rather than cremated, it had not been possible to bury the wife's remains together with those of the deceased in the garden of remembrance. The petition was supported by the incumbent and the archdeacon. The chancellor considered the guidance of the Court of Arches in Re Blagdon Cemetery [2002] Fam 299. He noted that the proposed reinterment was expressive of family unity and also freed up a space in the garden of remembrance. He noted the very short period between the death of the deceased and that of his wife and commented that the petition would have had much less weight had a period of ten years elapsed between the two deaths. The chancellor categorised the decision to inter the deceased's remains in the garden of remembrance as a 
'mistake' for the purposes of Blagdon Cemetery and stated that 'the correction of what can appropriately be described as a mistake within a short period does not seem to contradict the norm of the permanence of Christian burial'. The chancellor considered the similar facts in Re Christ Church, Alsager [1999] Fam 142 and considered that if the two sets of remains had had to be interred in different churchyards the petition would be stronger. Nevertheless, he found that the petition derived some strength from the fact that the deceased and his wife were buried so close together but separately, and considered that might be particularly upsetting to the family. The chancellor held that special circumstances existed and the faculty was granted. [RA]

doi:10.1017/So956618X1000061X

\section{Maga v Roman Catholic Archdiocese of Birmingham ${ }^{\mathrm{I}}$ \\ Court of Appeal: Neuberger MR, Longmore and Smith LJJ, March 2010 Child sexual abuse - priest - vicarious liability}

The claimant alleged that in the 1970s he had been serially sexually abused by an assistant priest in the Archdiocese of Birmingham. He appealed the decision of the High Court ([2009] EWHC 780 (QB), noted at (2009) 11 Ecc LJ 366) that the Archdiocese was not vicariously liable for the sexual abuse. The High Court had held that although the sexual abuse did take place, the priest's association with the claimant had nothing to do with the activities of the Church and was not part of evangelisation; moreover, although the Archdiocese had been negligent, it did not owe the claimant a duty of care. It was unreasonable to conclude that there was a duty to the world at large, and since there was no vicarious liability there was no duty of care. The Archdiocese cross-appealed, contending that the claim was time-barred, that the claimant had not been sexually abused and that the Archdiocese had not been negligent. The Court of Appeal allowed the claimant's appeal and dismissed the cross-appeal. Neuberger MR upheld the High Court's decision that the claim was not time-barred and that there had been sexual abuse. There was no evidence that Jack J had relied upon irrelevant evidence, ignored relevant evidence or misunderstood some evidence. However, he allowed the claimant's appeal and concluded that the abuse was 'so closely connected with [the priest's] employment' that it would be fair and just to hold the Archdiocese liable. The Archdiocese accepted that the priest should be treated as an employee for the purpose of this case; but counsel for the Archdiocese emphasised that this should not be taken as a general admission that a priest was, or was 